\title{
Study of interfacial microstructure, fracture energy, compressive energy and debonding load of steel fiber-reinforced mortar
}

\author{
Siaw Foon Lee $\cdot$ Stefan Jacobsen
}

Received: 11 July 2010/ Accepted: 28 January 2011/Published online: 23 February 2011

(C) The Author(s) 2011. This article is published with open access at Springerlink.com

\begin{abstract}
The properties of the interfacial transition zone (ITZ) of steel fiber and the bulk matrix were quantified using the backscattered electron imaging analysis (BSE-IA) and the scanning electron microscopy with energy dispersive X-ray analysis (SEMEDX), and their relationship with the mechanical properties of steel fiber-reinforced mortars was studied. The water and binder ratio $(w / b)$ of mortar, the amount of silica fume and steel fiber were varied. From the quantitative analysis, a higher build-up of calcium hydroxide was found from the steel fiber's interface up to 2 or $4 \mu \mathrm{m}$ distance away and its buildup was reduced with the $10 \%$ cement replacement by silica fume. Porosity in the ITZ and bulk matrix decreased the fracture energy, compressive energy and debonding load of steel fiber-reinforced mortar. However, its effect became marginal if a substantial amount of C-S-H or steel fibers appeared in the ITZ and bulk matrix, which increased the studied mechanical properties.
\end{abstract}

Keywords Interfacial transition zone . Backscattered electron imaging analysis . Scanning electron microscopy - Energy dispersive X-ray $\cdot$ Steel fiber-reinforced mortar

S. F. Lee $(\bowtie) \cdot$ S. Jacobsen

Department of Structural Engineering,

Norwegian University of Science and Technology,

7491 Trondheim, Norway

e-mail: siaw.lee@ntnu.no

\section{Introduction}

Concrete or mortar without reinforcement is brittle. In order to increase the ductility and the strength of concrete or mortar, different types of reinforcements such as steel bar [1], steel fiber [2], polymer [3], wollastonite micro-fibre [4] and carbon sheet [5] are often used. The increase in ductility and strength is mainly achieved by the stress transfer from the matrix to the reinforcements through the adhesive contact of paste surrounding the reinforcements.

The more paste is in contact with the surface of reinforcement, the higher the strength and the ductility of concrete and mortar are. However, due to the wall effect and bleeding, the matrix at the vicinity of aggregate and reinforcement showed higher porosity compared to the bulk matrix. This area is thus known as an interfacial transition zone (ITZ) between the reinforcement and the bulk matrix.

The thickness of ITZ depends on the water and cement ratio [6], whether the silica fume is used or not [7] and the diameter of reinforcement [8, 9]. Its thickness has been reported to range from 20 to $50 \mu \mathrm{m}$. If the reinforcement's diameter is bigger than the cement grains (typically $<80 \mu \mathrm{m}$ ), an ITZ will form around the reinforcement $[10,11]$. If the reinforcement's diameter is smaller than the cement grains, for example carbon fibers with $7 \mu \mathrm{m}$, no ITZ will form around the reinforcement [12]. From the SEM and X-ray diffraction study on the glass 'aggregate' surface, a duplex layer around $1-1.5 \mu \mathrm{m}$ thick that 
consists of a layer of calcium hydroxide $(\mathrm{CH})$ (first layer) and a layer of calcium-silicate-hydrate $(\mathrm{C}-\mathrm{S}-\mathrm{H})$ (second layer) is found in direct contact with the 'aggregate' surface. Then a relatively large hexagonal $\mathrm{CH}$ that develops adjacent to the duplex layer extends into the bulk matrix, together with a secondary deposit of stacked platelet $\mathrm{CH}$ fills the open space near the duplex layer [13].

The higher area percent $(\%)$ of porosity in ITZ and its thickness have been reported to exert an impact on the mechanical properties of concrete [14]. Therefore, it is essential to increase the particle packing in the ITZ so that the bond stress can be transferred optimumly. However, in some cases, it has been reported that the ITZ only gives a marginal effect on the mechanical properties of concrete [15]. A few methods have been adopted to reduce the porosity and the ITZ thickness, such as the improvement of curing, the incorporation of silica fume, polymeric additives and the reduction of water and binder ratio [16, 17]. Silica fume is commonly used to increase the compressive strength of concrete and mortar [18-20] because of its particle size of less than $1 \mu \mathrm{m}$ and its high content of amorphous silica $\left(\mathrm{SiO}_{2}\right)$ ( $>85 \%$ in general). These two characteristics allow silica fume to act not only physically as a filler to occupy the void in concrete but also chemically in the pozzolanic reaction with $\mathrm{CH}$ to form $\mathrm{C}-\mathrm{S}-\mathrm{H}$ gel that reduces the pores [21] and the permeability $[22,23]$ in the paste, and enhances the bond between the inclusion and the bulk matrix [24]. However, in some cases, the cement replacement of silica fume more than $10 \%$ by cement weight reduces the compressive strength of high-strength concrete [20], although the reason for that was not investigated by any means of microstructure analysis.

Quantitative analysis such as the backscattered electron imaging analysis (BSE-IA) and the energy dispersive X-ray analysis (EDX) have widely been adopted to investigate the porosity, $\mathrm{CH}, \mathrm{C}-\mathrm{S}-\mathrm{H}$ and unhydrated cement in the ITZ of aggregate [6], or in the ITZ of steel with a diameter of more than $9 \mathrm{~mm} \mathrm{[10],}$ without relating them to the mechanical properties. Since the improvement of the mechanical property of concrete or mortar involves the modification of paste microstructure or the inclusion of reinforcement or both at the same time, it is essential to investigate both the mechanical properties and the paste microstructure from the same specimen in order to have a thorough understanding of the effects taking place.
In this paper, steel fiber with a length of $13 \mathrm{~mm}$ and a diameter of $0.16 \mathrm{~mm}$ was used. Steel fiberreinforced mortars with $w / b 0.3$ and 0.5 , indicating high and medium strength mortars, were made. The cement replacement of silica fume by 0 and $10 \%$ by cement weight and the inclusion of 0.3 or 1 vol.\% steel fibers were performed on both $w / b$ to study their effects on micro-and macro-mechanical properties of steel fiber-reinforced mortars. Therefore, the specimens used for the mechanical tests were also adopted for the quantitative analysis of the porosity and cement hydrates in the ITZ of steel fiber extending to the bulk matrix using the BSE-IA and the SEM-EDX. The load-deflection curves and the compressive stress-strain curves were analyzed and related to the fracture mechanism that occurred in the mortars. The fracture energies, compressive energies and debonding loads were calculated. The relationship between the micro-properties in the ITZ and bulk matrix and the mechanical properties of steel fiberreinforced mortars are discussed.

\section{Experimental procedures}

0.3 vol.\% steel fibers were incorporated into mortars with two different $w / b, 0.3$ and 0.5 , with silica fume 0 and $10 \%$ by cement weight. Another mortar with $w / b 0.3$ without silica fume with 1 vol. $\%$ steel fibers was made for the comparison with 0.3 vol. $\%$ steel fibers. The materials used were Norcem Anlegg cement, which is an Ordinary Portland cement available commercially in Norway, silica fume (uncondensed), limestone powder, sand 0-2 $\mathrm{mm}$, sand 0-4 $\mathrm{mm}$, polycarboxylate polymer superplasticizer with $15 \%$ solids and the straight high carbon steel fibers with a length of $13 \mathrm{~mm}$ and a diameter of $0.16 \mathrm{~mm}$. The mix proportion ratios of materials of all mixes are stated in Table 1 . The chemical compositions of cement, silica fume and limestone powders are stated in Table 2 and the sieve analysis of fine aggregates in Table 3.

The fresh mortars were cast into $40 \times 40 \times$ $160 \mathrm{~mm}$ steel prism moulds and $50 \times 50 \times 50 \mathrm{~mm}$ steel cubic moulds respectively straight after the mixing. The moulds with fresh mortars were vibrated for $3 \mathrm{~s}$ on a vibrating table to ensure full compaction and then were covered with plastic bags. After $24 \mathrm{~h}$, the specimens were demoulded and cured in water at $20^{\circ} \mathrm{C}$ for 28 days before mechanical tests were performed. 
Table 1 Mix proportion ratios of steel fiber-reinforced mortars with $w / b 0.3$ and 0.5

\begin{tabular}{|c|c|c|c|c|c|}
\hline \multirow{2}{*}{$\begin{array}{l}\text { Materials } \\
\text { Cement }\left(\mathrm{kg} / \mathrm{m}^{3}\right)\end{array}$} & \multicolumn{3}{|l|}{ Water $/$ binder $=0.3$} & \multicolumn{2}{|c|}{ Water/binder $=0.5$} \\
\hline & 543.0 & 543.9 & 483.8 & 411.5 & 368.2 \\
\hline Silica fume $\left(\mathrm{kg} / \mathrm{m}^{3}\right)$ & - & - & $\begin{array}{l}48.4 \text { (10\% of } \\
\text { cement weight) }\end{array}$ & - & $\begin{array}{l}36.8 \text { ( } 10 \% \text { of } \\
\text { cement weight })\end{array}$ \\
\hline Limestone powder $\left(\mathrm{kg} / \mathrm{m}^{3}\right)$ & 47.2 & 47.3 & 47.4 & 47.3 & 47.9 \\
\hline Water $\left(\mathrm{kg} / \mathrm{m}^{3}\right)$ & 162.9 & 163.2 & 159.7 & 205.7 & 202.5 \\
\hline Sand $0-4 \mathrm{~mm}\left(\mathrm{~kg} / \mathrm{m}^{3}\right)$ & 1399.1 & 1382.1 & 1399.4 & 1399.4 & 1399.4 \\
\hline Sand $0-2 \mathrm{~mm}\left(\mathrm{~kg} / \mathrm{m}^{3}\right)$ & 246.9 & 243.9 & 246.9 & 246.9 & 246.9 \\
\hline Superplasticizer $\left(\mathrm{kg} / \mathrm{m}^{3}\right)$ & $\begin{array}{l}10.9 \text { ( } 2 \% \text { of } \\
\text { cement weight })\end{array}$ & $\begin{array}{l}11.4(2.1 \% \text { of } \\
\text { cement weight })\end{array}$ & $\begin{array}{l}12.1(2.5 \% \text { of } \\
\text { cement weight })\end{array}$ & $\begin{array}{l}4.9(1.2 \% \text { of } \\
\text { cement weight })\end{array}$ & $\begin{array}{l}6.4(1.73 \% \text { of } \\
\text { cement weight })\end{array}$ \\
\hline Steel fiber $\left(\mathrm{kg} / \mathrm{m}^{3}\right)$ & 24.2 (0.3 vol. \%) & 78.0 (1 vol.\%) & 23.4 (0.3 vol. \%) & $23.4(0.3$ vol. $\%)$ & $23.4(0.3$ vol. $\%)$ \\
\hline Designed air content & 2 vol. $\%$ & 2 vol. $\%$ & 2 vol. $\%$ & 2 vol. $\%$ & 2 vol. $\%$ \\
\hline Density $\left(\mathrm{kg} / \mathrm{m}^{3}\right)$ & 2,425 & 2,460 & 2,411 & 2,335 & 2,326 \\
\hline
\end{tabular}

Table 2 Chemical compositions of cement, silica fume and limestone powder

\begin{tabular}{lccc}
\hline Analysis (\%) & Cement & $\begin{array}{l}\text { Silica } \\
\text { fume }\end{array}$ & $\begin{array}{c}\text { Limestone } \\
\text { powder }\end{array}$ \\
\hline $\mathrm{CaO}$ & 63.50 & & 79.80 \\
$\mathrm{SiO}_{2}$ & 20.65 & $>90$ & 12.87 \\
$\mathrm{Al}_{2} \mathrm{O}_{3}$ & 4.70 & & 2.68 \\
$\mathrm{Fe}_{2} \mathrm{O}_{3}$ & 3.51 & & 2.04 \\
$\mathrm{SO}_{3}$ & 3.16 & & \\
$\mathrm{MgO}$ & 1.83 & & 1.84 \\
$\mathrm{~K}_{2} \mathrm{O}$ & 0.47 & & 0.62 \\
$\mathrm{Na}_{2} \mathrm{O}$ & 0.28 & & 0.49 \\
$\mathrm{P}_{2} \mathrm{O}_{5}$ & 0.11 & & \\
Loss of ignition & & $>3$ & 37.66 \\
Specific gravity $\left(\mathrm{g} / \mathrm{cm}^{3}\right)$ & 3.12 & 2.20 & 2.70 \\
Specific surface & 372 & & 362 \\
area (m & & \\
\hline
\end{tabular}

The three-point bending tests were carried out on three prisms using the Instron machine with a maximum load cell of $250 \mathrm{kN}$ at $20^{\circ} \mathrm{C}$ with the supporting span of $100 \mathrm{~mm}$ and the deflection rate of $0.1 \mathrm{~mm} / \mathrm{min}$. The compressive tests were carried out on six cubes at rate of $0.2 \mathrm{~mm} / \mathrm{min}$ using the Dartec machine with a maximum load cell of $20 \mathrm{kN}$ at $20^{\circ} \mathrm{C}$. The sampling rate for both the load and the deflection was $10 \mathrm{~Hz}$.

Porosity and unhydrated cement in the ITZ between steel fiber and bulk matrix were quantified using BSE-IA. A cube of $16 \times 16 \times 16 \mathrm{~mm}$ was cut from the middle of prism, with the direction of the polished surface in parallel with the direction of the
Table 3 Sieve analysis and physical properties of fine aggregates

\begin{tabular}{lcc}
\hline Sieve size $(\mathrm{mm})$ & Sand $0-2 \mathrm{~mm}$ & Sand 0-4 mm \\
\hline 8 & 100 & 100 \\
4 & 97.3 & 98.9 \\
2 & 91.8 & 85.9 \\
1 & 82.7 & 65.6 \\
0.5 & 68.1 & 40.9 \\
0.25 & 47.4 & 19.1 \\
0.125 & 23.6 & 6.1 \\
Fineness modulus & 1.51 & 2.37 \\
Specific gravity $\left(\mathrm{g} / \mathrm{cm}^{3}\right)$ & 2.65 & 2.65 \\
\hline
\end{tabular}

applied load as shown in Fig. 1. The polished surface of the specimen was ground using MD-grinding disc with grit size of $68,30,14,9 \mu \mathrm{m}$, vacuum impregnated with epoxy at 40 mbar, and then polished using MD-polishing cloths with grit size of $9,6,3,1$ and $1 / 4 \mu \mathrm{m}$. The lubricant, abrasive, force and duration adopted are shown in Table 4. A rotary Struers TegraPol-31 grinding and polishing machine was used. The surface was then coated with a layer of carbon. The image acquisition was carried out in the Hitachi S-3400N scanning electron microscopy (SEM) in backscattered electron mode with an accelerating voltage of $5 \mathrm{kV}$, a working distance of around $8 \mathrm{~mm}$ and a magnification of $500 \times$. Each image was digitized at $2560 \times 1920$ pixels with a resolution of $0.1 \mu \mathrm{m} /$ pixel. Only the steel fiber that was perpendicular to the image plain was chosen. $10-\mu \mathrm{m}$ wide strips were cut successively along the 
(a)

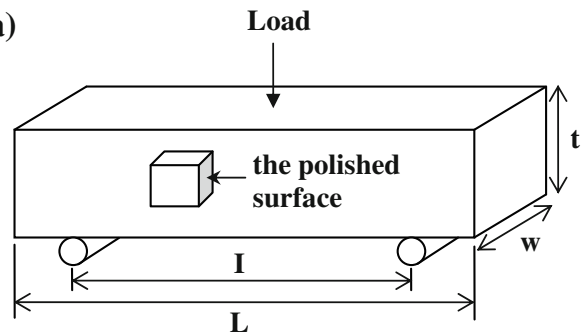

(b)

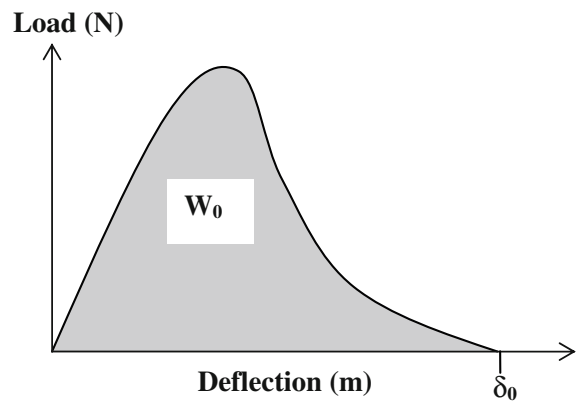

(c)

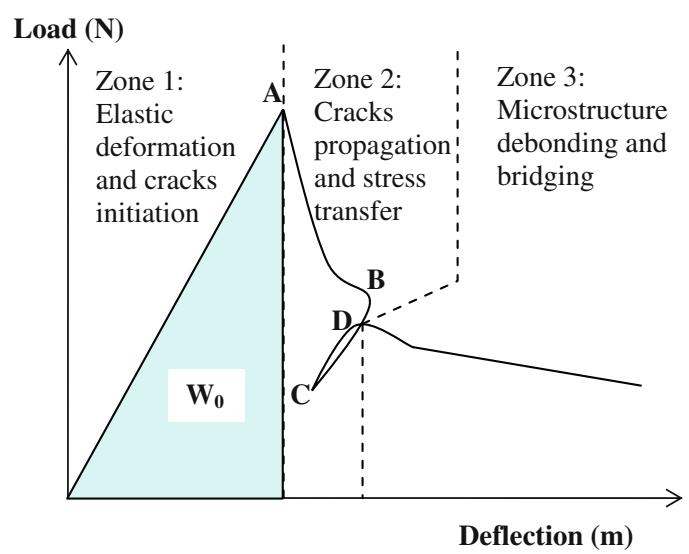

Fig. 1 Schematic diagrams of (a) a three-point bending test and a cube showing the direction of the polished surface used in our study, (b) a load-deflection curve without steel fiber, and (c) a load-deflection curve with steel fiber

periphery of the steel fiber using the Adobe Photoshop. Each $10-\mu \mathrm{m}$ wide strip was then analyzed for the area $\%$ of porosity and unhydrated cement using the analySIS ${ }^{\circledR}$. Figure 2 shows a typical greyscale histogram with the threshold cut-off value of 45 that is used for the porosity at $w / b 0.3$ and 0.5 . The upper threshold of the porosity was performed by adjusting the threshold setting and a visual-checking on the colored area in the BSE-image using the OXFORD INCA Features. The aggregates and some of the cement hydrates share the same range of greyscale in the histogram. Due to the limited technique that cannot remove the aggregates from the images in our study, only porosity and unhydrated cement in the ITZ of steel fiber were quantified using the BSE-IA.

The EDX analysis on the ITZ between steel fiber and bulk matrix was carried out using the Hitachi S-3400N SEM at an accelerating voltage of $15 \mathrm{kV}$. The main elements detected were $\mathrm{Al}, \mathrm{Si}, \mathrm{Ca}$ and $\mathrm{Fe}$ with their absorption edge voltage for $K_{\alpha}$ as $1.49,1.74,3.69$ and 6.40 respectively. In order to have a good detection on one element, the accelerating voltage should be at least 2-3 times higher than the absorption edge voltage of the element. Therefore, an accelerating voltage of $15 \mathrm{kV}$ was chosen in our study. The $\mathrm{X}$-ray line analysis was performed right under and above three different steel fibers for each mix. Each X-ray line consisted of 20 points with a distance of $2 \mu \mathrm{m}$ between each point. $\mathrm{The} \mathrm{Ca} / \mathrm{Si}$ ratio was calculated for each point and plotted against the distance from the steel fiber's interface. It was reported that the $\mathrm{Ca} / \mathrm{Si}$ value for $\mathrm{C}-\mathrm{S}-\mathrm{H}$ was from 0.8 to 2.5 ; for $\mathrm{CH}$ was above 10 and for monosulfate (AFm) was above 4 [25].

\section{Fracture and compressive energy calculation and debonding load measurement}

Among all the mechanical properties, the fracture energy, the compressive energy and the debonding load stand out as one of the most suitable measurements for evaluating the strength of steel fiberreinforced mortars and provide an insight into the influence of porosity and microstructure on the fracture process. Therefore, they were calculated and measured using the definition and equation in the following.

Fracture energy is defined as the amount of energy required to create a unit area of crack in the matrix. According to the RILEM 50-FMC Draft Recommendation [26], the fracture energy, $G_{\mathrm{F}}$, of a plain mortar is calculated using the following equation:

$G_{\mathrm{F}}=\frac{\left(W_{0}+m g \delta_{0}\right)}{A}$

where $W_{0}(\mathrm{Nm})$ is the dissipated energy represented by the whole area under the load-deflection curve obtained from the three-point bending test, $m=m_{1}+m_{2}(\mathrm{~kg})$, with $m_{1}$ the weight of the beam between the supports, $m_{2}$ the weight of the part of the loading arrangement which is not attached to the machine but follows the beam until failure, $g\left(\mathrm{~m} / \mathrm{s}^{2}\right)$ 
Table 4 Grinding discs, polishing cloths, lubricant/abrasive, force and duration used for grinding and polishing

\begin{tabular}{|c|c|c|c|}
\hline & Lubricant/Abrasive & Force $(\mathrm{N})$ & Duration (min) \\
\hline \multicolumn{4}{|l|}{ (1) MD-grinding disc } \\
\hline MD-Piano 220 (68 $\mu \mathrm{m}$ diamond) & Water & 20 & 2 \\
\hline MD-Piano 600 (30 $\mu \mathrm{m}$ diamond) & Water & 20 & 2 \\
\hline MD-Piano 1200 (14 $\mu$ m diamond) & Water & 20 & 2 \\
\hline MD-Largo & Ethanol/9 $\mu \mathrm{m}$ diamond grit suspensions & 15 & 2 \\
\hline \multicolumn{4}{|l|}{ (2) MD-polishing cloths } \\
\hline MD-Plan & Blue ethanol/6 $\mu \mathrm{m}$ diamond grit spray & 10 & 2 \\
\hline MD-Dur & Ethanol/3 $\mu \mathrm{m}$ diamond grit suspensions & 10 & 2 \\
\hline MD-Dac & Ethanol/1 $\mu \mathrm{m}$ diamond grit suspensions & 10 & 2 \\
\hline MD-Nap & Blue ethanol/1/4 $\mu \mathrm{m}$ diamond grit spray & 10 & 1 \\
\hline
\end{tabular}

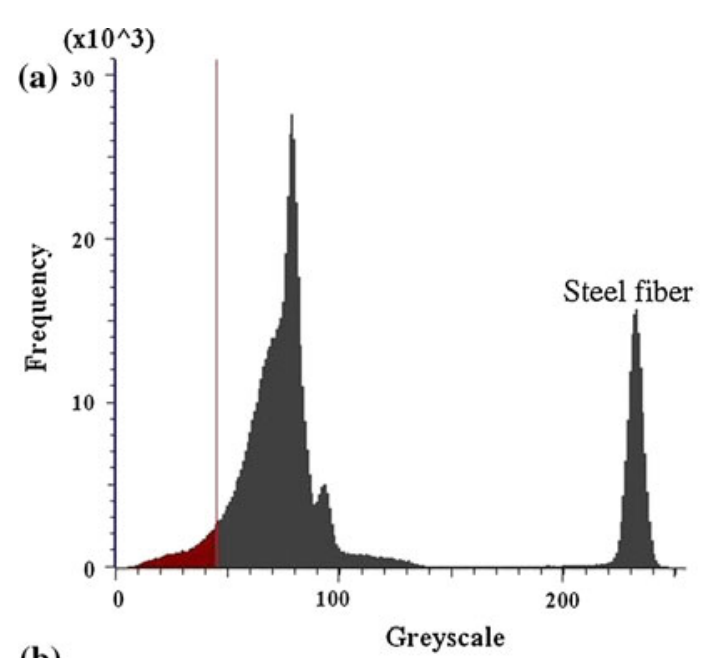

(b)

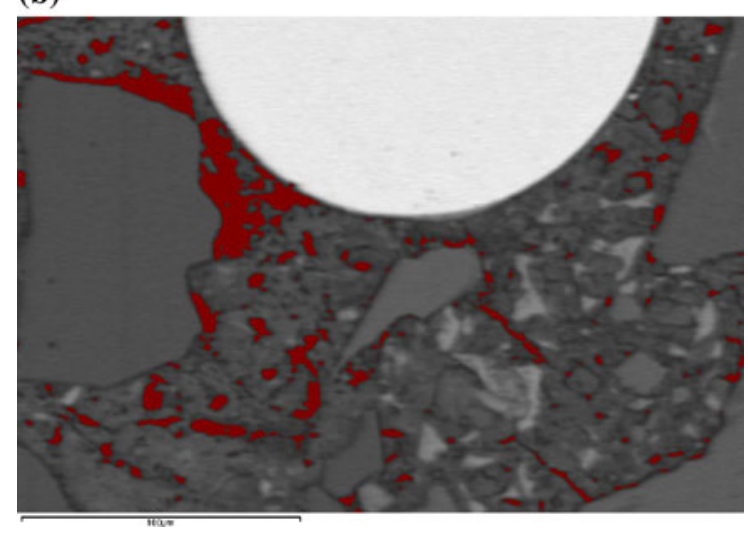

Fig. 2 A typical greyscale histogram that corresponds to a typical BSE-image, with the isolated right peak referring to the steel fiber

the acceleration due to gravity, $\delta_{0}(\mathrm{~m})$ the deformation at the final failure of the beam, and $A\left(\mathrm{~m}^{2}\right)$ the area of the ligament, which is $w \times t$, see Fig. 1 .
In this study, steel fiber-reinforced mortars were made. Therefore, for the calculation of $G_{\mathrm{F}}$ of a steel fiber-reinforced mortar using the Eq. $1, \mathrm{~W}_{0}$ was the area under the load-deflection curve from zero up to the deflection at the maximum load, see Fig. 1c. The calculated $G_{\mathrm{F}}$ is thus defined as the energy needed for cracks to initiate and propagate in a unit area of the matrix of a steel fiber-reinforced mortar until fracture failure. After the maximum load, the bridging and pullout of steel fiber happened and this involved the cementhydrate debonding at the interfaces of steel fibers. Since $G_{\mathrm{F}}$ greatly depends on the specimen size [27], in this study, all prisms' sizes were made at $40 \times 40 \times$ $160 \mathrm{~mm}$ for the ease of $G_{\mathrm{F}}$ comparison due to the effect of $10 \%$ silica fume and different vol.\% of steel fibers.

As for the calculation of compressive energy, the load-deflection curves obtained from the compressive tests were converted into engineering stressstrain curves. The engineering stress, $\sigma$, is defined as the uniaxial load at time $t, F_{\mathrm{t}}$, divided by the original cross-sectional area of mortar, $A_{0}$ :

$\sigma=\frac{F_{\mathrm{t}}}{A_{0}}$

And the engineering strain is the change in height divided by the original height:

$\varepsilon=\frac{h_{\mathrm{t}}-h_{0}}{h_{0}}$

with $h_{0}$ is the original height of the mortar and $h_{\mathrm{t}}$ is the height at time $t$.

Mortar is brittle in nature and the cross-sectional area of mortar does not expand uniformly with the applied load as polymeric materials [28, 29]. 


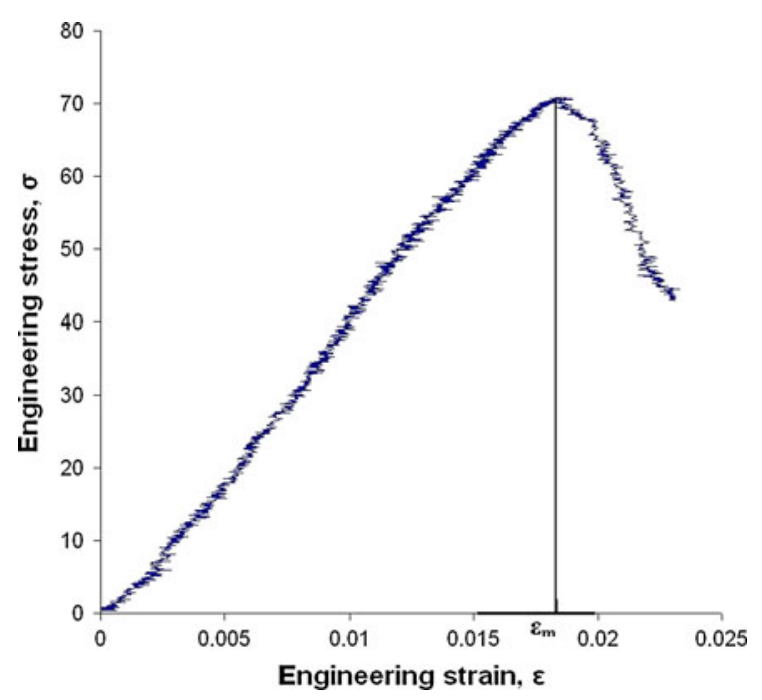

Fig. 3 A typical compressive stress and strain curve of steel fiber-reinforced mortar

Therefore, the calculation of compressive energy from the true stress-strain curve is not applied to the mortar although it gives a more accurate data than from the engineering stress-strain curve. The compressive energy, $W_{\mathrm{c}}$, of steel fiber-reinforced mortar is thus the area under the engineering stress-strain curve from zero up to the strain at the maximum load, $\varepsilon_{\mathrm{m}}$, as shown in Fig. 3 using the following equation:

$$
\int_{0}^{\varepsilon_{m}} \sigma d \varepsilon
$$

In this study, the debonding load is a measure of the applied load at the onset of the cement-hydrate debonding at the steel fibers' interfaces that takes place in the load-deflection curve obtained from the three-point bending test.

\section{Experimental results and discussion}

\subsection{Load-deflection behaviours}

\subsubsection{Mortar with 0.3 vol.\% steel fiber at two different $w / b$}

Figure 4 shows a typical load-deflection curve of mortar with 0.3 vol.\% steel fibers obtained from our three-point bending test, displaying the applied load from zero until the deflection where the steel fibers

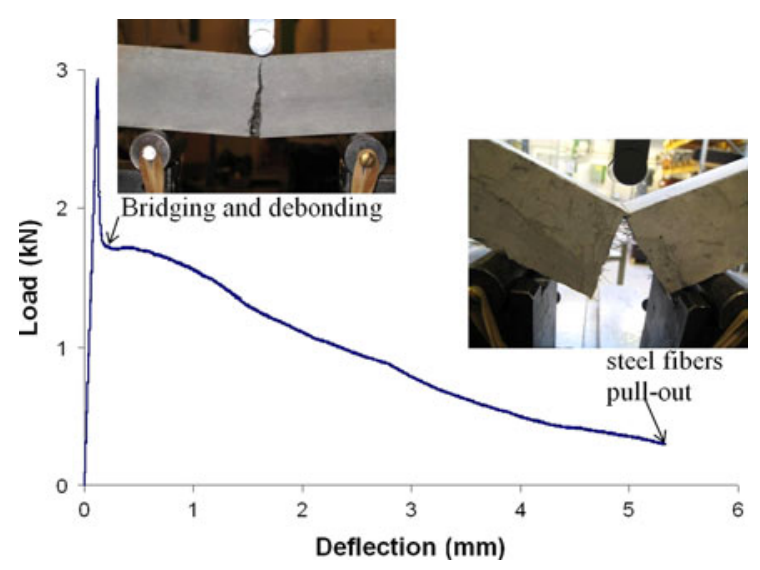

Fig. 4 A typical load-deflection curve for mortar with 0.3 vol.\% steel fibers obtained from the three-point bending test, showing a linear relationship between the applied load and the deflection before the maximum load is exceeded, then a bridging and finally fibers pull-out

being completely pulled out. When the load-deflection curves of mortars with 0.3 vol.\% steel fibers with $w / b 0.3$ and 0.5 from zero to the deflection of around $0.6 \mathrm{~mm}$ were plotted as shown in Figs. 5 and 6 , different curves after the maximum applied load were discerned. The load-deflection curves can then be subdivided into three zones as in the schematical drawing in Fig. 1. In zone 1, an elastic deformation takes place in the mortar and the cracks start to initiate at the deflection when the applied load reaches about 70-90\% of the maximum load [30]. In zone 2, a fracture failure happens in the mortar matrix, and at the same time, the applied load is transferred from breaking the mortar into half to pulling the steel fibers out from the matrix. In zone 3, the cement-hydrate debonding takes place at the steel fiber's interface, followed by the steel fibers being pulled out along the matrix before a complete failure of a steel fiber-reinforced mortar.

All mortars display similar curves in zone 1 and zone 3 but not in zone 2 . The factors that cause the difference in the fracture curves of mortars in zone 2 are mainly the change of $w / b$ and the cement replacement of silica fume. Mortars with $w / b 0.3$ shows a distinct decrease in deflection before the applied load drops to the minimum compared to mortars with $w / b 0.5$. For mortars with silica fume for both $w / b$, an elastic deformation is shown before the cementhydrate debonding occurs at the steel fiber's interface and it is more distinct at $w / b 0.3$ than at $w / b 0.5$. 

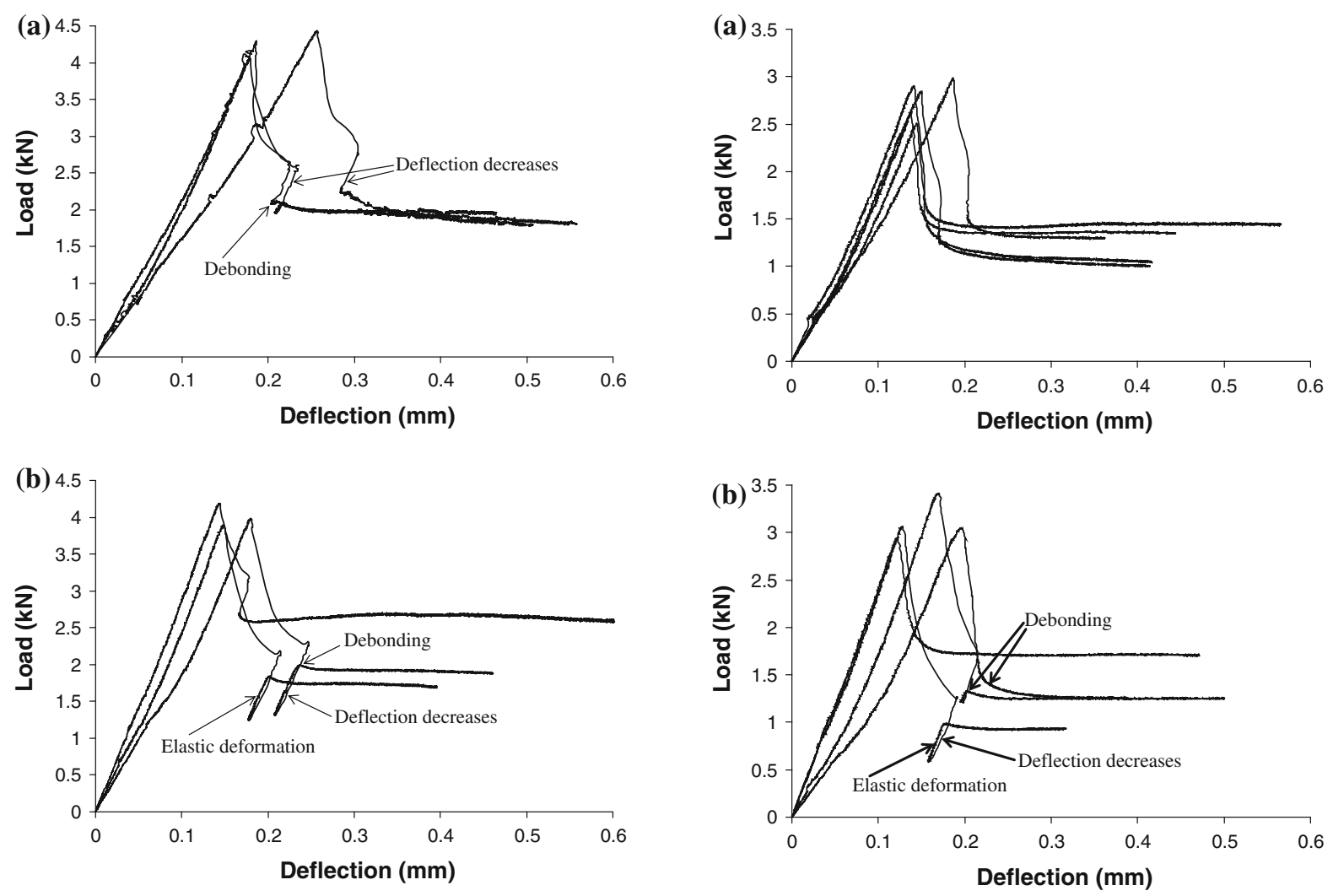

Fig. 5 Load-deflection curves for mortars with $w / b \quad 0.3$ (a) without, and (b) with $10 \%$ silica fume incorporated with 0.3 vol.\% steel fiber. From two out of three curves in (b), an elastic deformation is seen before the cement-hydrate debonding takes place at the steel fibers' interfaces

A decrease in deflection in zone 2, which is less than $0.036 \mathrm{~mm}$ as shown in Table 5 , reflects that the steel fibers are pushed back slightly into the matrix through the relaxation of the paste. The decreaseddeflection and the elastic deformation curves in zone 2 are almost parallel to the curve of the elastic deformation of mortar in zone 1, indicating that it was the cement hydrates that involved, not because of the relaxation of the machine.

\subsubsection{Mortar with 0, 0.3 and 1 vol.\% steel fiber at the same $w / b$}

Figure 7 shows three different load-deflection curves for mortars with $w / b 0.3$ without silica fume incorporated with $0,0.3$ and 1 vol. $\%$ steel fibers. The fracture curves in zone 2 are different from each other. For plain mortars, regardless of $w / b$, the applied load falls rapidly to zero straight after the

Fig. 6 Load-deflection curves for mortars with $w / b 0.5$ (a) without, and (b) with $10 \%$ silica fume incorporated with 0.3 vol.\% steel fiber. From two out of four curves in (b), an elastic deformation is seen before the cement-hydrate debonding takes place at the steel fibers' interfaces

maximum load is exceeded. For mortars with steel fibers, 1 vol. $\%$ steel fibers arrest the applied load from falling earlier than $0.3 \mathrm{vol} \%$ steel fibers, in addition, three out of five curves show strain hardening just after the maximum load, see Fig. 8.

\subsection{Engineering stress and strain curves}

Regardless of $w / b$, mortars with and without steel fibers show similar engineering stress-strain curves as in Fig. 3. Therefore, it is difficult to study the effect of steel fiber and silica fume on the fracture mechanism in the mortars from the curves. In this case, only the compressive energy was calculated from the curves. However, the photos taken on the cubes after the uniaxial compressive tests show that the steel fibers have an effect on the fracture modes of mortars, see Fig. 9. For mortars without steel fibers, the cracks initiated from the top and the middle of 
Table 5 The compressive energy, the fracture energy, the debonding load, the decreased deflection and the deflection at maximum load of steel fiber-reinforced mortars

\begin{tabular}{|c|c|c|c|c|c|}
\hline \multirow[b]{2}{*}{ Silica fume ( $\%$ by cement weight) } & \multicolumn{3}{|l|}{$w / b=0.3$} & \multicolumn{2}{|l|}{$w / b=0.5$} \\
\hline & 0 & & 10 & 0 & 10 \\
\hline Steel fiber (vol.\%) & 0.3 & 1 & 0.3 & 0.3 & 0.3 \\
\hline Compressive energy, $W_{\mathrm{c}} \pm \Delta W_{\mathrm{c}}(\mathrm{J})$ & $81 \pm 6$ & $113 \pm 14$ & $101 \pm 6$ & $37 \pm 4$ & $46 \pm 3$ \\
\hline Fracture energy, $G_{\mathrm{F}} \pm \Delta G_{\mathrm{F}}\left(\mathrm{J} / \mathrm{m}^{2}\right)$ & $214 \pm 43$ & $269 \pm 7$ & $200 \pm 8$ & $125 \pm 14$ & $131 \pm 9$ \\
\hline Debonding load, $L_{\mathrm{d}} \pm \Delta L_{\mathrm{d}}(\mathrm{kN})$ & $2160 \pm 88$ & $4575 \pm 547$ & $2141 \pm 328$ & $1459 \pm 128$ & $1429 \pm 329$ \\
\hline Close-up deflection, $\Delta(\mathrm{B}-\mathrm{C})(\mathrm{mm})$ & $0.015-0.023$ & - & $0.006-0.036$ & - & $0.018-0.030$ \\
\hline Deflection at maximum load (mm) & $0.180-0.257$ & $0.210-0.251$ & $0.149-0.181$ & $0.138-0.188$ & $0.123-0.198$ \\
\hline
\end{tabular}

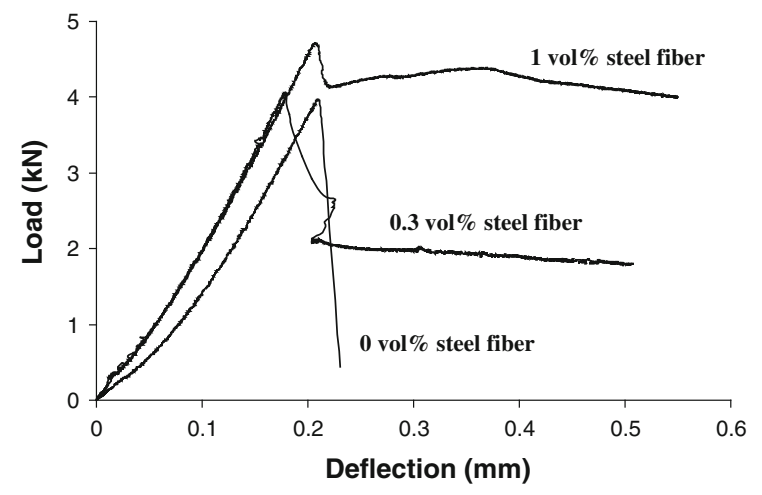

Fig. 7 Load-deflection curves for mortars with $w / b \quad 0.3$ without silica fume incorporated with $0,0.3$ and 1 vol. $\%$ steel fiber

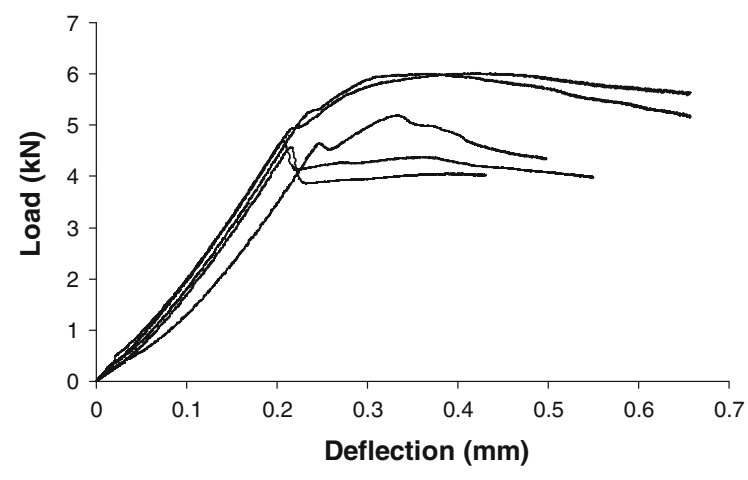

Fig. 8 Load-deflection curves for mortars with $w / b \quad 0.3$ without silica fume incorporated with 1 vol.\% steel fiber

both sides of the cubes at around $20-45^{\circ}$ from the direction of the uniaxial applied load and then coalesced together. This led to big pieces of mortar to fall apart from both sides of the cubes. However, mortars with steel fibers, the cracks initiated in the
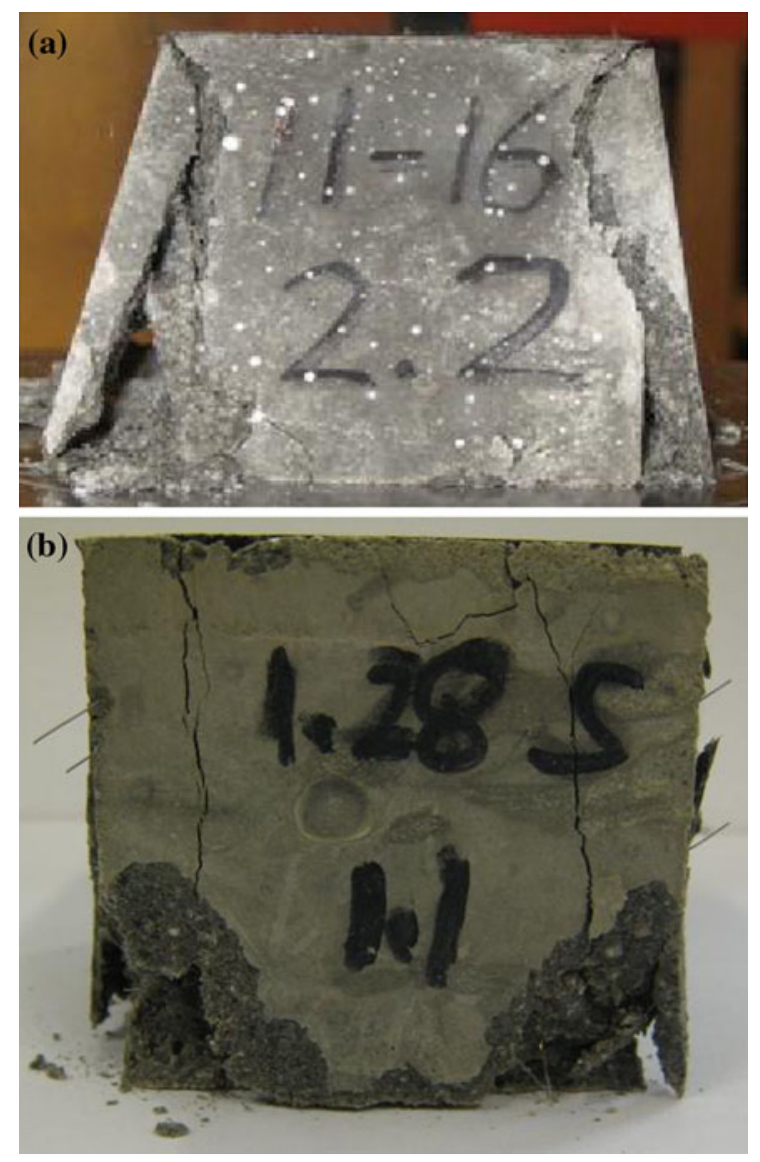

Fig. 9 The fracture modes of mortars: (a) without steel fibers and (b) with steel fibers

same direction as the uniaxial applied load with one small transverse crack and big pieces of mortar from both sides were held from falling apart. Since the fracture mode is not the main concern in this study, a detailed work is not provided here. 


\subsection{Backscattered electron images}

The composite structure of steel fiber-reinforced mortar depends on the mix proportions of materials and the efficiency of mixing. Before the BSE-IA and SEM-EDX were performed, the composite structure of the specimen was studied using the SEM. Figure 10 shows the ITZ of a steel fiber extending to the bulk matrix and the neighbouring aggregates for mortars with $w / b 0.3$ and 0.5 . Due to the fact that the steel fibers having a diameter of $0.16 \mathrm{~mm}$ and the aggregates having sizes less than $4 \mathrm{~mm}$, more overlaps of ITZ aureoles are found in the specimen [15]. Occasionally, porous zone around those steel fibers that cluster together is seen, as shown in Fig. 11. No void due to bleeding forms at the bottom of steel fiber in mortars with $w / b 0.3$ and 0.5 [31]. This indicates that the mixing without segregation was achieved and the formation of cement hydrates in the ITZ of steel fiber was mainly influenced by the wall effect and the degree of hydration. Microcracks are found in mortars with $w / b$ 0.3. As shown in Fig. 10a-left, microcracks do not initiate from any pores that close to the steel fiber's interface. They are at a right angle to the steel fiber's interface and propagate through the bulk matrix and end up at a right angle on the interface of a neighbouring aggregate. On top of that, some small microcracks that do not initiate from any pores are also seen in the ITZ or the bulk matrix in mortars with $w / b 0.3$ due to dessication. No agglomeration of silica fume was found in the specimens for both $w / b$ [32]. Therefore, for the quantitative analysis of porosity and cement hydrates using the BSE-IA and the SEM-EDX, we selected the steel fiber that was located as far away as possible from any interaction of aggregate to avoid ITZ aureole and with no microcrack so that the intrinsic properties of the paste in the ITZ extending to the bulk matrix could be studied.

\subsection{Porosity and unhydrated cement in ITZ and bulk matrix}

Figure $12 \mathrm{a}$ and $\mathrm{b}$ shows the curves of area $\%$ of porosity and unhydrated cement versus distance from the steel fiber's interface for $w / b 0.3$ and 0.5. Each data point in each curve shown in Fig. 12a and b represents an average of area fractions of six steel fibers' ITZs

(a)

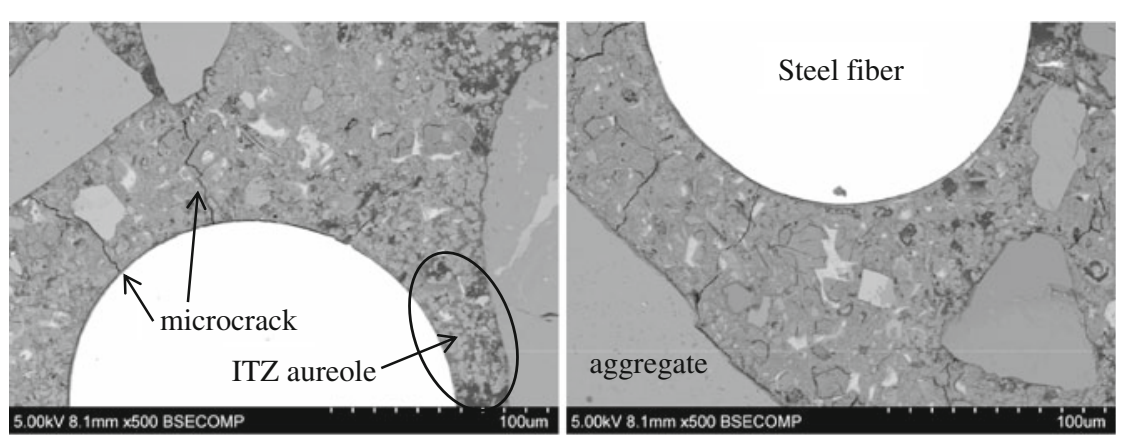

(b)

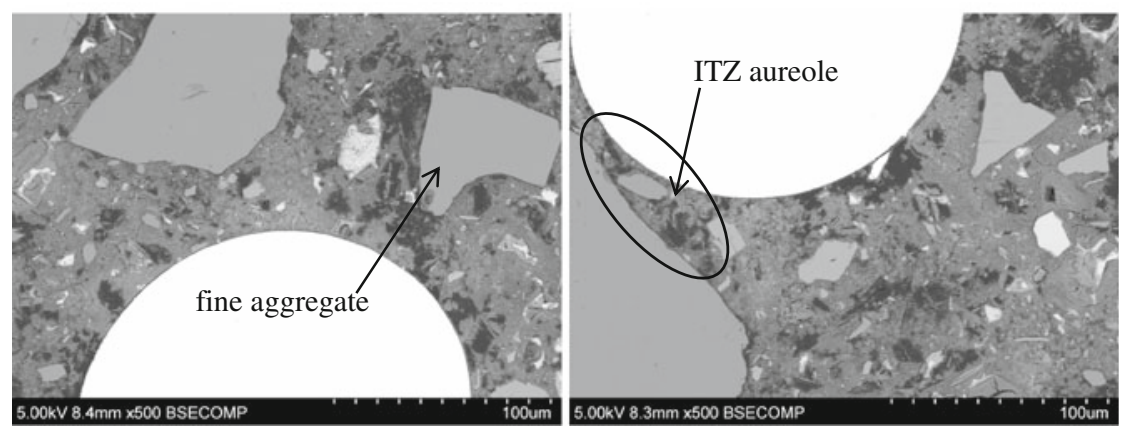

Fig. 10 The BSE images of the top side (left) and the bottom side (right) of the ITZ and the bulk matrix of steel fibers in mortars with (a) $w / b 0.3$ and (b) $w / b 0.5$. The bright round object is steel fiber 


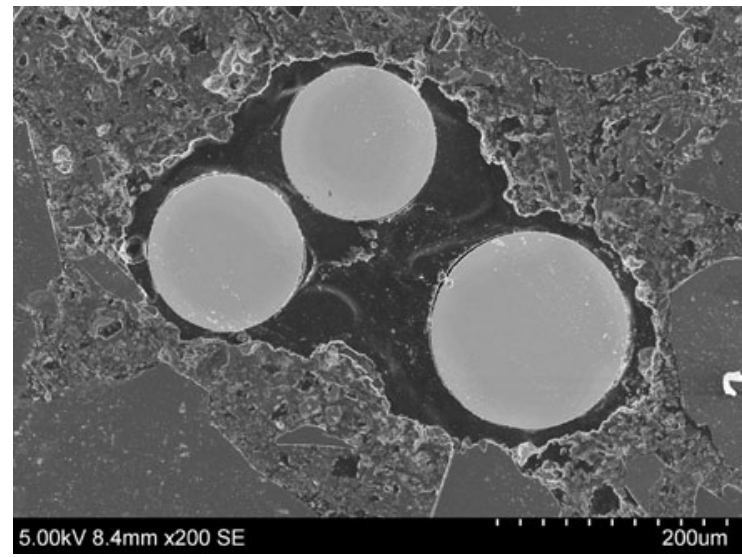

Fig. 11 A porous area is found around the steel fibers that agglomerated together
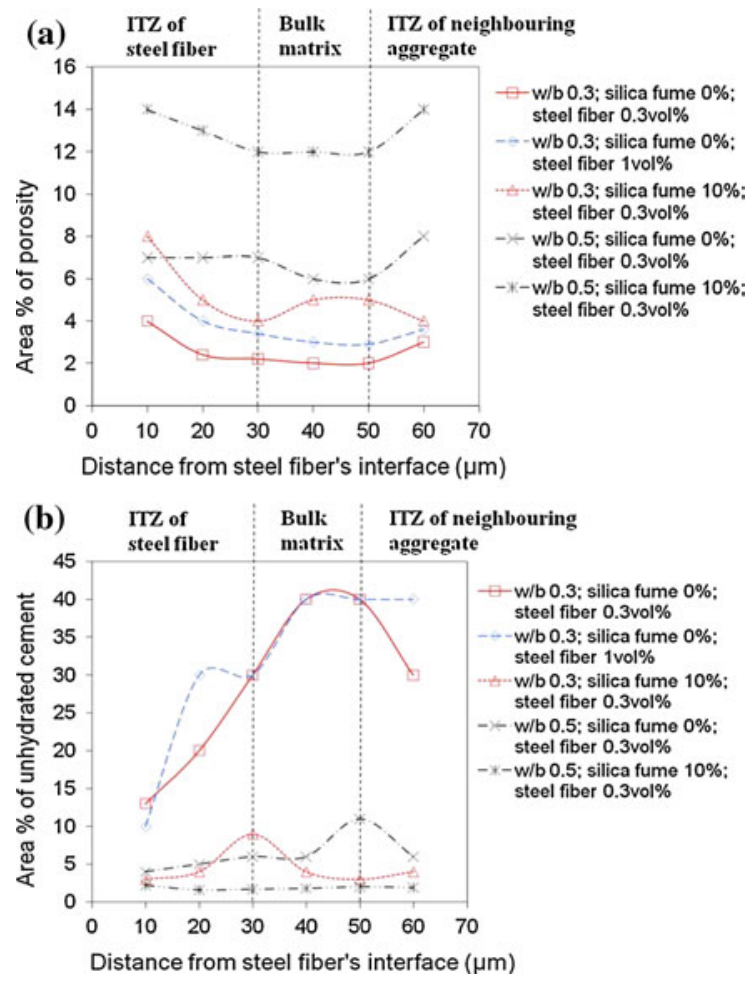

Fig. 12 Microstructural curves in the ITZ and the bulk matrix of steel fibers in the mortars with $w / b 0.3$ and 0.5 : (a) porosity and (b) unhydrated cement grain

from two specimens of the same $w / b$. The distance studied from the steel fiber's interface was from 10 up to $60 \mu \mathrm{m}$. The resolution of the pore sizes can be detected in our study is $0.1 \mu \mathrm{m} /$ pixel $[33,34]$.
Therefore, only the coarse-capillary porosity was measured in the ITZ between the steel fiber and the bulk matrix.

For the mortar with $w / b 0.3$, a sharp gradient in area \% of porosity is shown from the steel fiber's interface to $20 \mu \mathrm{m}$ away and then it reaches a plateau at $30 \mu \mathrm{m}$. For the mortar with $w / b 0.5$ without silica fume, the area $\%$ of porosity shows a constant value from 10 to $30 \mu \mathrm{m}$ away from the steel fiber's interface; however, with $10 \%$ silica fume, a gradient is shown from the steel fiber's interface to $30 \mu \mathrm{m}$. From the study of the porosity gradient of both $w / b$, a steel fiber with a diameter of $0.16 \mathrm{~mm}$ included into the mortars with the maximum aggregate size $<4 \mathrm{~mm}$ has an ITZ thickness of around 20-30 $\mu \mathrm{m}$. The bulk matrix is then at the distance of 30-50 $\mu \mathrm{m}$ away from the steel fibers. An ITZ belonging to a neighbouring aggregate is encountered at the distance of $50 \mu \mathrm{m}$ away from the steel fiber, therefore, a sudden increase in area $\%$ of porosity is seen in the curve. From the BSE images, most of the small particles such as the limestone powders $(57.2 \%<24 \mu \mathrm{m})$ that were not involved in the chemical reaction [35] or the fine aggregates $<0.125 \mathrm{~mm}$ tended to deposit close to the steel fibers. If the paste formed surrounding the fine aggregate is dense, a decrease in porosity at $40 \mu \mathrm{m}$ away from the steel fiber's interface is seen; if it is loose, an increase in porosity at $40 \mu \mathrm{m}$ away from the steel fiber's interface is seen.

The $w / b 0.5$ has higher area $\%$ of porosity and lower area \% of unhydrated cement in the ITZ and the bulk matrix compared to $w / b 0.3$, and this is mainly due to the availability of higher water and lower cement powder content involved in the cement hydration in the case of $w / b 0.5$.

Silica fume has been reported to have effects in densifying the cement paste due to its smaller particle size to fill the pores and its pozzolanic reaction with $\mathrm{CH}$ to form $\mathrm{C}-\mathrm{S}-\mathrm{H}[22,23]$. However, from the quantitative analysis of the area $\%$ of porosity for both $w / b$, mortars with $10 \%$ silica fume show higher area $\%$ of porosity than that without silica fume even though the inclusion of $10 \%$ silica fume reduces the area $\%$ of unhydrated cement compared to that without silica fume. It has reported that the filling effect of silica fume [32] and the compressive strength of concrete [36] reduce if the silica fume is not dispersed properly in the matrix. Under the SEM examination as mentioned in the Sect. 4.3, the 
agglomeration of silica fume [32] was not found in the ITZ of steel fiber and bulk matrix of our specimens. If the agglomeration of silica fume happened to our specimens and no filling effect from the silica fume, the same area $\%$ of porosity should be shown in both $w / b$ with and without $10 \%$ silica fume. On the other hand, there has been research about the effect of silica fume on the pore structure of cement paste. According to Buil et al. [37], the pozzolanic reaction of silica fume with $\mathrm{CH}$ led to large voids $(1-10 \mu \mathrm{m})$, which corresponded to the initial $\mathrm{CH}$ crystals sites that had not been filled up after 28-day curing. Zhang et al. [38] showed that silica fume reduced the content of fine pores but increased the content of large pores $(>0.5 \mu \mathrm{m})$ in cement paste using the mercury porosimetry method. The increase in area $\%$ of porosity in the ITZ of steel fiber in our mortars with $10 \%$ silica fume using the BSE-IA is in agreement with that of Buil et al. [37] and Zhang et al. [38]. As for the area \% of unhydrated cement, silica fume only replaced the cement powder by $10 \%$ of cement weight with the volume fraction of the water remaining the same in the mixtures with and without silica fume for both $w / b$, see Table $1[18,19]$. This explains the higher degree of hydration in the mortars with silica fume for both $w / b$, as shown in Fig. 12b.

Figure 12 shows that for mortars with $w / b 0.3$ and with 0.3 and 1 vol.\% steel fibers, the ITZ and the bulk matrix at 1 vol. $\%$ steel fibers have higher area $\%$ of porosity than that at $0.3 \mathrm{vol} . \%$, although the area $\%$ of unhydrated cement remains the same in the ITZ and the bulk matrix for both vol.\% steel fibers. In the mix proportion shown in Table 1 , the inclusion of steel fibers actually replaced some aggregates in terms of vol.\%, with the rest of the components remaining unchanged. Steel fibers have a higher surface-volume ratio compared to aggregates. The increase of the amount of steel fibers definitely increased the total surface area. Therefore, the amount of paste that deposited around each steel fiber was reduced, and this led to higher area $\%$ of porosity in the ITZ and the bulk matrix of 1 vol.\% steel fibers.

\section{5 $\mathrm{Ca} / \mathrm{Si}$ ratio in ITZ and bulk matrix}

Figure 13 shows the $\mathrm{Ca} / \mathrm{Si}$ ratio at the top and the bottom of the steel fibers versus the distance from the steel fiber's interface. The X-ray line analysis was performed at the top and the bottom of three different steel fibers in the mortars of the same $w / b$. The $\mathrm{Ca} / \mathrm{Si}$ ratios of three different areas were plotted in the same graph to see the distribution of $\mathrm{CH}, \mathrm{C}-\mathrm{S}-\mathrm{H}$ and $\mathrm{AFm}$ in the ITZ and the bulk matrix of steel fibers of each mix. All graphs are displayed with the maximum axis of $\mathrm{Ca} / \mathrm{Si}$ ratio at 35 so that the data points of $\mathrm{Ca} / \mathrm{Si}$ ratio between 0 and 2.5 are clearly shown for comparison. Therefore, this causes the data points with the $\mathrm{Ca} / \mathrm{Si}$ value more than 35 to be removed from some of the graphs. The $\mathrm{Ca} / \mathrm{Si}$ ratio at zero distance refers to the area very close to the interface of a steel fiber. The $\mathrm{Ca} / \mathrm{Si}$ ratio $=0$ in the region of $22-40 \mu \mathrm{m}$, as shown in Fig. 13c-right, is due to the presence of a fine aggregate which was silicious sand in this study. $63.5 \%$ of cement powders and $79.8 \%$ of limestone powders are $\mathrm{CaO}$ (see Table 2). The presence of unhydrated cement and limestone powder in $w / b 0.3$ and 0.5 contributes to the Ca content. Due to that, not all the $\mathrm{Ca} / \mathrm{Si}$ ratio $>10$ calculated refers to the presence of $\mathrm{CH}$, especially the high peak found at the distance of $30 \mu \mathrm{m}$ from the steel fiber's interface, see Fig. 13. This was confirmed by checking the location of the data point in the BSE image where the data point was taken.

The quantitative analysis reveals that a noncontinuous layer of large quantity of $\mathrm{CH}$ together with a non-continuous layer of $\mathrm{C}-\mathrm{S}-\mathrm{H}$ and a small quantity of AFm form on the interface of a steel fiber for both $w / b$. A higher build-up of $\mathrm{CH}$ is mainly found from the steel fiber's interface to a distance of 2 or $4 \mu \mathrm{m}$ away, which is consistent with the discovery of a relatively large deposition of $\mathrm{CH}$ close to the duplex film reported by Barnes et al. [13]. A large quantity of C-S-H is found depositing after $8 \mu \mathrm{m}$ for $w / b 0.3$ and after $4 \mu \mathrm{m}$ for $w / b 0.5$. The replacement of cement by $10 \%$ silica fume reduces the build-up of $\mathrm{CH}$ close to the steel fiber's interface, with the reduction of $\mathrm{CH}$ being more in $w / b 0.3$ than in $w / b 0.5$.

The trends of the $\mathrm{CH}, \mathrm{C}-\mathrm{S}-\mathrm{H}$ and $\mathrm{AFm}$ distributions in the ITZ and the bulk matrix of the steel fibers in $w / b \quad 0.3$ with 0.3 and 1 vol.\% steel fibers are similar. Since the inclusion of steel fibers only replaced some aggregate and not the binder composition, it was unlikely that the $\mathrm{Ca} / \mathrm{Si}$ ratio was influenced by the amount of steel fibers included in the mortars. 

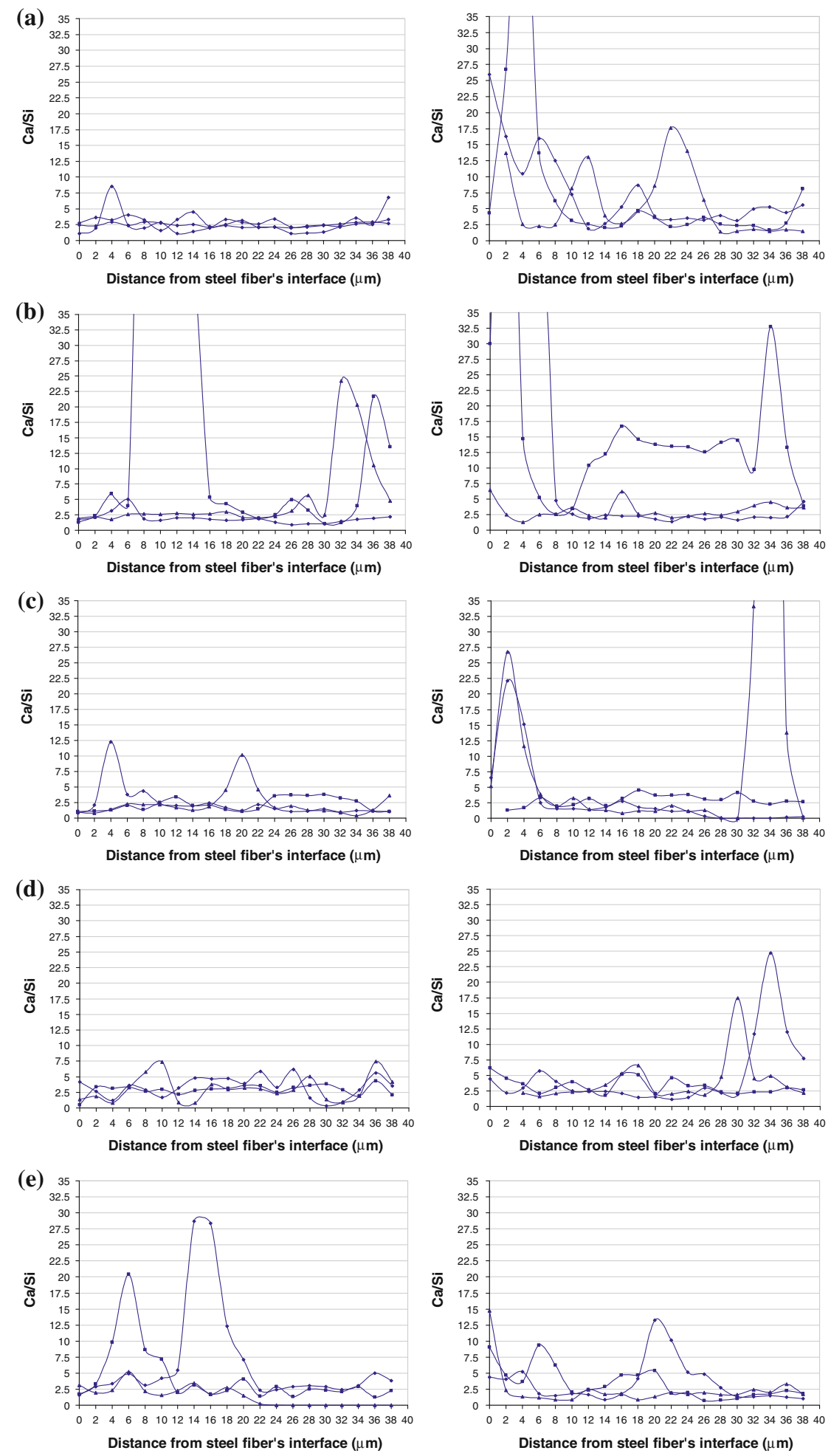

Fig. 13 Chemical composition curves in the ITZ and the bulk matrix of the top side (left) and the bottom side (right) of steel fibers: (a) $w / b 0.3$ without $10 \%$ silica fume (sf) with 1 vol. $\%$ steel

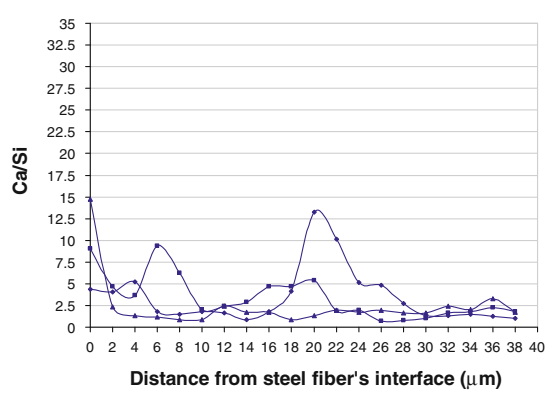

fiber (st), (b) $w / b 0.3$ without $10 \%$ sf with 0.3 vol. $\%$ st, (c) $w / b 0.3$ with $10 \%$ sf with 0.3 vol. $\%$ st, (d) $w / b 0.5$ without $10 \%$ sf with 0.3 vol. $\%$ st, and (e) $w / b 0.5$ with $10 \%$ sf with 0.3 vol. $\%$ st 
4.6 Effect of porosity and microstructure on mechanical properties

Table 5 shows the fracture energies, compressive energies, and debonding loads of a series of steel fiber-reinforced mortars that were made in this study. Three cases that relate the porosity and microstructure to the studied mechanical properties are drawn as below:

(1) Mortars with $w / b 0.3$ show higher compressive energies, fracture energies and debonding loads than mortars with $w / b 0.5$. This is mainly due to the low porosity and high cement-hydrate packing in the ITZ and bulk matrix at $w / b 0.3$, which is confirmed from the BSE-IA data presented in Sect. 4.4.

(2) Applying $10 \%$ silica fume to both $w / b$ with 0.3 vol.\% steel fibers, most of the mortars with $10 \%$ silica fume show higher fracture and compressive energies than those without $10 \%$ silica fume, and both have similar debonding loads. Although $10 \%$ silica fume increases the porosity in the ITZ and bulk matrix, it also increases the amount of $\mathrm{C}-\mathrm{S}-\mathrm{H}$ that gives strength to the mortar through the pozzolanic reaction [39]. This implies that if silica fume is not dispersed properly in the mortar, an increased amount of $\mathrm{C}-\mathrm{S}-\mathrm{H}$ through the pozzolanic reaction cannot be achieved, regardless of $w / b$. This explains a drop in the mechanical properties of mortars reported by others [20].

(3) Comparing mortars with $w / b 0.3$ and with 0.3 and 1 vol.\% steel fibers, 1 vol.\% has higher debonding load, compressive and fracture energies than 0.3 vol. $\%$. In addition, 1 vol. $\%$ shows strain hardening after the maximum load. However, the BSE-IA shows that 1 vol.\% has higher area $\%$ of porosity in the ITZ and bulk matrix than 0.3 vol.\%. An increased amount of 0.7 vol.\% steel fibers that helps in arresting, forcing the propagation of cracks through more tortuous paths and bridging the cracks outweighs the overlap of ITZ aureoles and the porosity in bulk matrix. Therefore, an increase in debonding load, compressive and fracture energy is seen in $1 \mathrm{vol} \%$.

The above discussion show that for a composite material such as steel fiber-reinforced mortar, the porosity, the amount of $\mathrm{C}-\mathrm{S}-\mathrm{H}$ and the vol.\% of reinforcement are closely related to each other in influencing the studied mechanical properties. The higher the porosity, the lower the cement-hydrate packing is in the ITZ and bulk matrix. Therefore, less cement hydrates are for strengthening the paste matrix, for the adhesion and stress transfer between steel fiber and paste matrix. However, the effect of porosity on the studied mechanical properties will become marginal if a substantial amount of $\mathrm{C}-\mathrm{S}-\mathrm{H}$, which gives strength to the mortar, or a substantial vol.\% of reinforcement, which arrests, forces the cracks propagating through more tortuous paths and bridges the cracks, are included in the mortar. On top of that, this study also shows that $10 \%$ silica fume that is dispersed properly in the mortar evolves completely in the pozzolanic reaction to produce $\mathrm{C}-\mathrm{S}-\mathrm{H}$. Due to that, no silica fume is left for filling the pores.

Different types of cement hydrates in the ITZ have a tendency in influencing the way that the stress is transferred from the bulk matrix to the steel fiber. $\mathrm{CH}$ is crystalline and $\mathrm{C}-\mathrm{S}-\mathrm{H}$ is amorphous [39]. From the quantitative analysis of the $\mathrm{Ca} / \mathrm{Si}$ ratio, more $\mathrm{C}-\mathrm{S}-\mathrm{H}$ forms in the ITZs of steel fibers for mortars with $10 \%$ silica fume after 28-day curing. Due to that, an elastic deformation before the debonding at the steel fiber's interface is shown on the load-deflection curves of steel fiber-reinforced mortars with $10 \%$ silica fume. In order to have the elastic deformation before debonding, the bonds between the cement hydrates and the steel fiber's interface must be ductile; otherwise, no elastic deformation will be shown if the bond is brittle. This study reveals that the bond formed between $\mathrm{C}-\mathrm{S}-\mathrm{H}$ and steel fiber's interface is ductile and the bond formed between $\mathrm{CH}$ and steel fiber's interface is brittle.

\section{Conclusions}

This research work led to the following conclusions:

(1) $10 \%$ silica fume that was dispersed properly in the mix not only increased the amount of $\mathrm{C}-\mathrm{S}-\mathrm{H}$ through the pozzolanic reaction but also increased the coarse-capillary porosity in the ITZ and bulk matrix of steel fiber, regardless of $w / b$. 
(2) For steel fiber-reinforced mortars, the porosity, the amount of $\mathrm{C}-\mathrm{S}-\mathrm{H}$ and the vol.\% of steel fibers were related to each other in influencing the fracture energy, compressive energy and debonding load. The effect of porosity in decreasing the studied mechanical properties could be suppressed when a substantial amount of $\mathrm{C}-\mathrm{S}-\mathrm{H}$ or steel fibers appeared in the mortar.

(3) The inclusion of 1 vol.\% steel fibers in a mortar outweighed the cement replacement of silica fume by $10 \%$ cement weight in terms of the improvement of the studied mechanical properties of steel fiber-reinforced mortars, although both increased the porosity in the paste matrix.

Acknowledgments We thank the funding from the Norwegian University of Science and Technology (NTNU) and the Norwegian Research Council (NRC) through the Institution-based Strategic Project (ISP) on focus area 3-Sustainable Infrastructure (Grant No. 177275). This work also forms a part of NTNU's contribution to the Concrete Innovation Centre (COIN) at Sintef/NTNU, starting in 2007 as a centre for research based innovation (CRI) within concrete technology with 9 industrial partners: Aker Solutions, Norcem Heidelberg, Borregaard, Maxit, Skanska, Rescon Mapei, UNICON, Veidekke and the Norwegain Road directory.

Open Access This article is distributed under the terms of the Creative Commons Attribution Noncommercial License which permits any noncommercial use, distribution, and reproduction in any medium, provided the original author(s) and source are credited.

\section{References}

1. Apostolopoulos CA, Papadakis VG (2008) Consequences of steel corrosion on the ductility properties of reinforcement bar. Constr Build Mater 22:2316-2324

2. Qian C, Indubhushan P (1999) Properties of high-strength steel fiber-reinforced concrete beams in bending. Cem Concr Compos 21:73-81

3. Zeris C, Anastasakis J, Kyriakidis J (2009) Investigation of monotonic and cyclic response of fiber-reinforced polymer strengthened beams. ACI Struct J 106:3-13

4. Low NMP, Beaudoin JJ (1994) The flexural toughness and ductility of Portland cement-based binders reinforced with wollastonite micro-fibres. Cem Concr Res 24:250-258

5. Kim YJ, Shi C, Green MF (2008) Ductility and cracking behavior of prestressed concrete beams strengthened with prestressed CFRP sheets. J Compos Constr 12:274-283

6. Elsharief A, Cohen MD, Olek J (2003) Influence of aggregate size, water cement ratio and age on the microstructure of the interfacial transition zone. Cem Concr Res 33:1837-1849
7. Xuan DX, Shui ZH, Wu SP (2009) Influence of silica fume on the interfacial bond between aggregate and matrix in near-surface layer of concrete. Constr Build Mater 23:2631-2635

8. Cwirzen A, Penttala V (2005) Aggregate-cement paste transition zone properties affecting the salt-frost damage of high-performance concretes. Cem Concr Res 35:671-679

9. Stucke MS, Majumdar AJ (1976) Microstructure of glass fibrereinforced cement composites. J Mater Sci 11:1019-1030

10. Horne AT, Richardson IG, Brydson RMD (2007) Quantitative analysis of the microstructure of interfaces in steel reinforced concrete. Cem Concr Res 37:1613-1623

11. Chen H, Sun W, Zhao Q, Sluys LJ, Stroeven P (2007) Effects of fiber curvature on the microstructure of the interfacial transition zone in fresh concrete. Front Archit Civ Eng China 1:99-106

12. Katz A, Bentur A (1995) Effect of matrix composition on the aging of CFRC. Cem Concr Compos 17:87-97

13. Barnes BD, Diamond S, Dolch WL (1978) Contract zone between Portland cement paste and glass aggregate. Cem Concr Res 8:233-244

14. Akşaoğlu T, Tokyay M, Çelik T (2005) Assessing the ITZ microcracking via scanning electron microscope and its effect on the failure behavior of concrete. Cem Concr Res 35:358-363

15. Diamond S, Huang J (2001) The ITZ in concrete-a different view based on image analysis and SEM observations. Cem Concr Compos 23:179-188

16. Bentz DP, Stutzman PE (2006) Curing, hydration, and microstructure of cement paste. ACI Mater J 103:348-356

17. Rossignolo JA (2009) Interfacial interactions in concretes with silica fume and SBR latex. Constr Build Mater 23:817-821

18. Mazloom M, Ramezanianpour AA, Brooks JJ (2004) Effect of silica fume on mechanical properties of highstrength concrete. Cem Concr Compos 26:347-357

19. Kadri E-H, Duval R, Aggoun S, Kenai S (2009) Silica fume effect on hydration heat and compressive strength of high-performance concrete. ACI Mater J 106:107-113

20. Yogendran V, Langan BW, Haque MN, Ward MA (1987) Silica fume in high-strength concrete. ACI Mater J 84:124-129

21. Mehta PK, Gjrv OE (1982) Properties of Portland cement concrete containing fly ash and condensed silica-fume. Cem Concr Res 12:587-595

22. Toutanji H, McNeil S, Bayasi Z (1998) Chloride permeability and impact resistance of polypropylene-fiber-reinforced silica fume concrete. Cem Concr Res 28:961-968

23. Bagheri AR, Alibabaie M, Babaie M (2008) Reduction in the permeability of plastic concrete for cut-off walls through utilization of silica fume. Constr Build Mater 22:1247-1252

24. Goldman A, Bentur A (1989) Bond effect in high-strength silica-fume concretes. ACI Mater J 86(5):440-447

25. Taylor HFW, Newbury DE (1984) An electron microprobe study of a mature cement paste. Cem Concr Res $14: 565-573$

26. RILEM 50-FMC Draft Recommendation (1985) Determination of the fracture energy of mor-tar and concrete by means of three-point tests on notched beams. Mater Struct $18: 287-290$ 
27. Hillerborg A (1985) Results of three comparative test series for determining the fracture energy GF of concrete. Mater Struct 18:407-413

28. Lee SF, Swallowe GM (2004) Direct measurement of high rate stress-strain curves using instrumented falling weight and high-speed photography. Imaging Sci J 52(4):193-201

29. Lee SF, Swallowe GM (2006) Quasi-static and dynamic compressive behavior of poly(methylmethacrylate) and polystyrene at temperatures from $293 \mathrm{~K}$ to $363 \mathrm{~K}$. J Mater Sci 41:6280-6289

30. Hsu TTC, Slate FO, Sturman GM, Winter G (1963) Microcracking of plain concrete and the shape of the stressstrain curve. ACI J Proc 60(2):209-224

31. Igarashi S, Bentur A, Mindess S (1996) The effect of processing on the bond and interfaces in steel fiber reinforced cement composites. Cem Concr Compos 18:313-322

32. Diamond S, Sahu S (2006) Densified silica fume: particle size and dispersion in concrete. Mater Struct 39:849-859

33. Igarashi S, Kawamura M, Watanabe A (2004) Analysis of cement pastes and mortars by a combination of backscatter-based SEM image analysis and calculations based on the Powers model. Cem Concr Compos 26:977-985
34. Powers TC, Brownyard TL (1947) Part 5-studies of the physical properties of hardened Portland cement paste. ACI J Proc 43:669-712

35. Ye G, Liu X, Schutter G, Poppe A-M, Taerwe L (2007) Influence of limestone powder used as filler in SCC on hydration and microstructure of cement pastes. Cem Concr Compos 29:94-102

36. Toutanji HA (1995) The influence of silica fume on the compressive strength of cement paste and mortar. Cem Concr Res 25:1591-1602

37. Buil M, Delage P (1987) Some further evidence on a specific effect of silica fume on the pore structure of Portland cement mortars. Cem Concr Res 17:65-69

38. Zhang MH, Gjørv OE (1991) Effect of silica fume on pore structure and chloride diffusivity of low porosity cement pastes. Cem Concr Res 21:1006-1014

39. Tabor D (1981) Principles of adhesion-bonding in cement and concrete. In: Kreijgerm PC (ed) Adhesion problems in the recycling of concrete. Plenum Press, New York, pp 63-87 